\title{
The Albanensia finds from Hungary and Romania
}

\author{
János Hír \\ Municipal Museum of Pásztó \\ H-3060 Pásztó, Múzeum tér 5, Hungary. \\ E-mail:hirjanos@gmail.com
}

\begin{abstract}
A comprehensive study of the flying squirrel Albanensia finds of the two countries is given. The smallest and earliest representative of the genus is the species Albanensia sansaniensis. It has been recently found in the Badenian (Middle Miocene) fauna of Szentendre. Some sporadic Albanensia sp. and Albanensia albanensis finds were described from Sarmatian localities. Significant Albanensia grimmi materials are known from the late Sarmatian fauna of Felsötárkány $3 / 2$ and the early Pannonian fauna of Rudabánya. This latter sample has some special characters, which differ from typical A. grimmi finds from Felsőtárkány 3/2, Götzendorf, Richardhof, and Hammerschmiede. With 27 figures and 8 tables.
\end{abstract}

Key words - Central Paratethys, Middle Miocene, rodents, systematics, terrestrial faunas

\section{INTRODUCTION}

Albanensia is a large-sized flying squirrel which is a characteristic element of the European Miocene rodent faunas from the early Miocene MN4 Zone to the late Miocene MN10 Zone. In the Pannonian Basin important new materials were collected by the author during the last two decades. Some of them were mentioned in earlier papers (HÍR 2003, 2006, 2015; HíR et al. 2011; Hír \& VENCZEL 2018). The aim of this publication is the comprehensive description and valuation of these findings with the revised investigation of the assemblage from Rudabánya.

\section{ABBREVIATIONS AND METHODS}

D4: upper deciduous (milk) premolar;

P3: upper third permanent premolar;

P4: upper fourth permanent premolar;

M1-M2-M3: upper permanent molars;

d4: lower deciduous (milk) premolar; 
p4: lower fourth permanent premolar;

m1-m2-m3: lower permanent molars;

L: maximal antero-posterior length on the occlusal surface of the tooth crown;

W: maximal linguo-labial width on the occlusal surface of the tooth crown;

No. inv: inventory number;

MMP: Municipal Museum of Pásztó;

MGSH: Collection of Mining and Geological Survey of Hungary;

ISER: Institut de Speleologie Emile Racovița, Bucharest.

Morphological nomenclature of the occlusal surface of the teeth is after Cuenca Bescos (1988), Daxner-Höck $(2004,2010)$, and Daxner-Höck \& HöcK (2015) (Figs 1, 2). Measurements were taken by the ocular micrometer of MBS-10 stereomicroscope.

The dimensions are given in $\mathrm{mm}$. Micrographs were taken by Canon Eos 400 digital camera with a Canon MP-E- $65 \mathrm{~mm}$ macroobjective. Retouching was conducted by the author.

\section{SYSTEMATIC PALAEONTOLOGY}

Family: Sciuridae Fischer von Waldheim, 1817

Subfamily: Pteromyinae Brandt, 1855

Genus: Albanensia Daxner-Höck et Mein, 1975

Type species - Albanensia albanensis (Major, 1893), La Grive Saint-Alban M, France, N7/8

Diagnosis - "Sciuroptere mit grossen Backenzähnen; Shmelzrunzeln an Kauflächen; komplizierterer Bau der Oberkiefer-gegenüben den Unterkiefermolaren, Die Oberkieferzähne besitzen kein freies Mesostyl. Der Hypoconus ist Kräftig. P4 grösser als M1. M3 besitzt einen Metaloph. Die Unterkieferzähne haben kein freistehendes Mesostylid. Vorder- und Schlusscingulum können wie die Talonidsenke gerunzelt sein. Hypoconulid auf Schluscingulum möhlich. Labialen Art des Vordercingulums und vordere Aussenbucht fehlen."

Diagnosis translated from German - Flying squirrel with large molars. Upper and lower molars are equally characterised by complicated enamel structure. No free mesostyle in the upper molars. The hypocone is strong. P4 is larger than M1. M3 has a metaloph. No independent mesostylid in the lower molars. The anterior and posterior cingula can be undulated like the talonid basin. The presence of hypoconulid is possible on the posterior cingula. The labial branch of the anterocingulum and the anterolabial bay is missing. 


\section{Albanensia sansaniensis (Lartet, 1851)}

(Figs 3, 7, 10, 11, 15, 19, 23, Table 1)

2018 Albanensia sansaniensis (Lartet) - Hír \& VenCZeL, pp. 48-51.

Locality - Szentendre.

The finds were collected by the author during the field-campaigns organized in 2018 and 2019. The locality is identical to the place of discovery which was first published by KorDOs $(1982,1986)$. Up to the present only a preliminary publication has been given on the results of the new excavation (Hír \& VENCZEL 2018).

Material -

Table 1. Individual data of the Albanensia teeth from Szentendre

\begin{tabular}{|c|c|c|c|c|c|}
\hline Locality & No. inv. MMP & Position & $\mathrm{L}$ & $\mathrm{W}$ & Figures in the present paper \\
\hline Szentendre & 2019.600 & P4 & 2.60 & 2.87 & \\
\hline Szentendre & 2019.722 . & P4 & 2.80 & 2.90 & Fig. 3 \\
\hline Szentendre & 2019.723 & P4 & 2.70 & 3.0 & \\
\hline Szentendre & 2019.599. & M1-2 & 2.72 & 3.3 & \\
\hline Szentendre & 2018.431. & M1-2 & 2.65 & 3.3 & Fig. 7 \\
\hline Szentendre & 2019.688 & M3 & 3.10 & 3.17 & Fig. 11 \\
\hline Szentendre & 2018.433 & $\mathrm{~d} 4$ & 2.07 & 1.77 & \\
\hline Szentendre & 2018.434. & $\mathrm{p} 4$ & 2.7 & 2.5 & Fig. 10 \\
\hline Szentendre & 2018.435. & $\mathrm{~m} 1$ & 2.65 & 2.77 & Fig. 15 \\
\hline Szentendre & 2018.436 & $\mathrm{~m} 1$ & 2.62 & 2.75 & \\
\hline Szentendre & 2018.440 & $\mathrm{~m} 1$ & 2.67 & 2.90 & \\
\hline Szentendre & 2019.725. & $\mathrm{~m} 1$ & 2.52 & 2.77 & \\
\hline Szentendre & 2018.437. & $\mathrm{~m} 2$ & 2.95 & 3.0 & Fig. 19 \\
\hline Szentendre & 2018.438 & $\mathrm{~m} 2$ & 2.87 & 2.90 & \\
\hline Szentendre & 2018.439. & $\mathrm{~m} 2$ & 2.95 & 3.12 & \\
\hline Szentendre & 2019.726 & $\mathrm{~m} 2$ & 2.87 & 3.22 & \\
\hline Szentendre & 2018.441. & $\mathrm{~m} 3$ & 3.37 & 3.20 & \\
\hline Szentendre & 2019.727 & $\mathrm{~m} 3$ & 3.60 & 3.15 & Fig. 23 \\
\hline
\end{tabular}

Morphological description - P4 - Subtriangular outline with rounded angles. There is a protuberant parastyle on the mesial part of the tooth crown which has no additional cusp on its lingual or labial side. Secondary ridges are not developed in the sinuses. Protoloph and metaloph do not form zigzag crests like the same ridges in the upper teeth of $A$. grimmi (in the interpretation of DAXNER- 


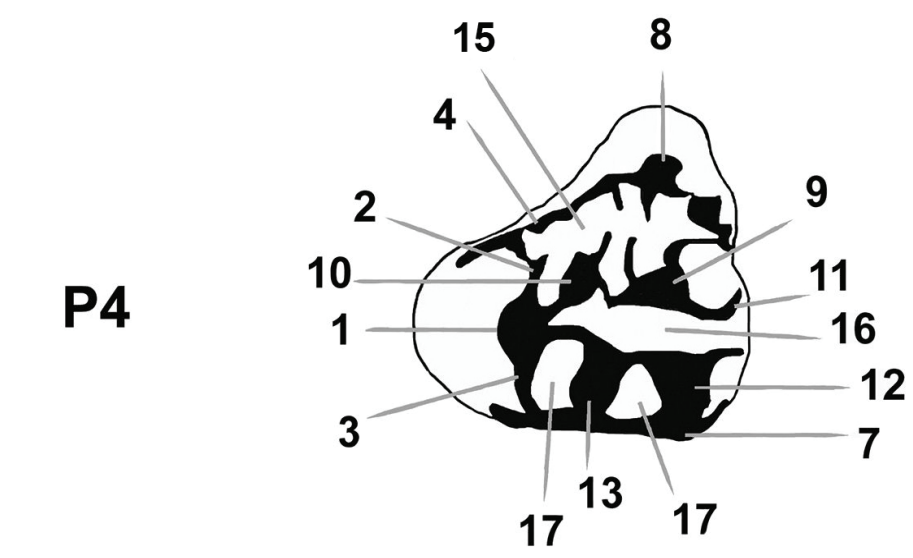

M1-2

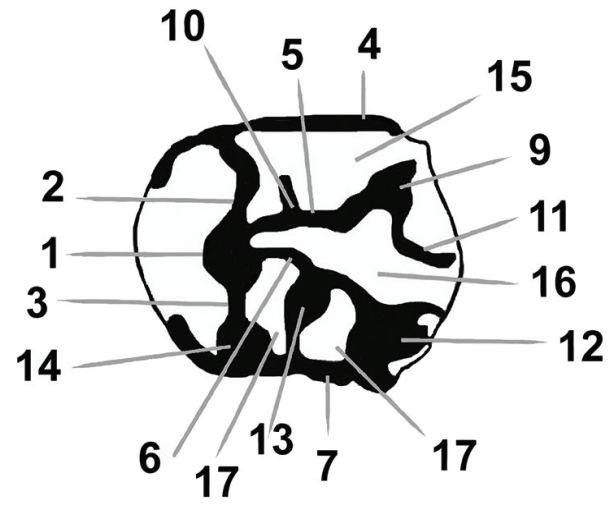

\section{M3}

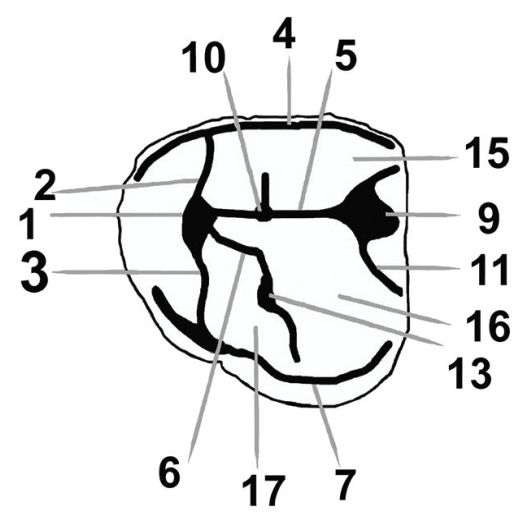

Fig. 1. Morphological nomenclature of Albanensia upper P4, M1-2, M3 (after Cuenca Bescos 1988; DAXNER-Hö CK 2004, 2010). 1 = protocone; $2=$ protocone anterior $\mathrm{arm} ; 3=$ protocone posterior $\operatorname{arm} ; 4=$ anteroloph $5=$ protoloph; $6=$ metaloph; $7=$ posteroloph; $8=$ parastile; $9=$ paracone; $10=$ protoconule; $11=$ mesostyle crista and mesostyle; $12=$ metacone; $13=$ metaconule; $14=$ hypocone $; 15=$ anterosinus $; 16=$ central sinus $; 17=$ posterosinus 


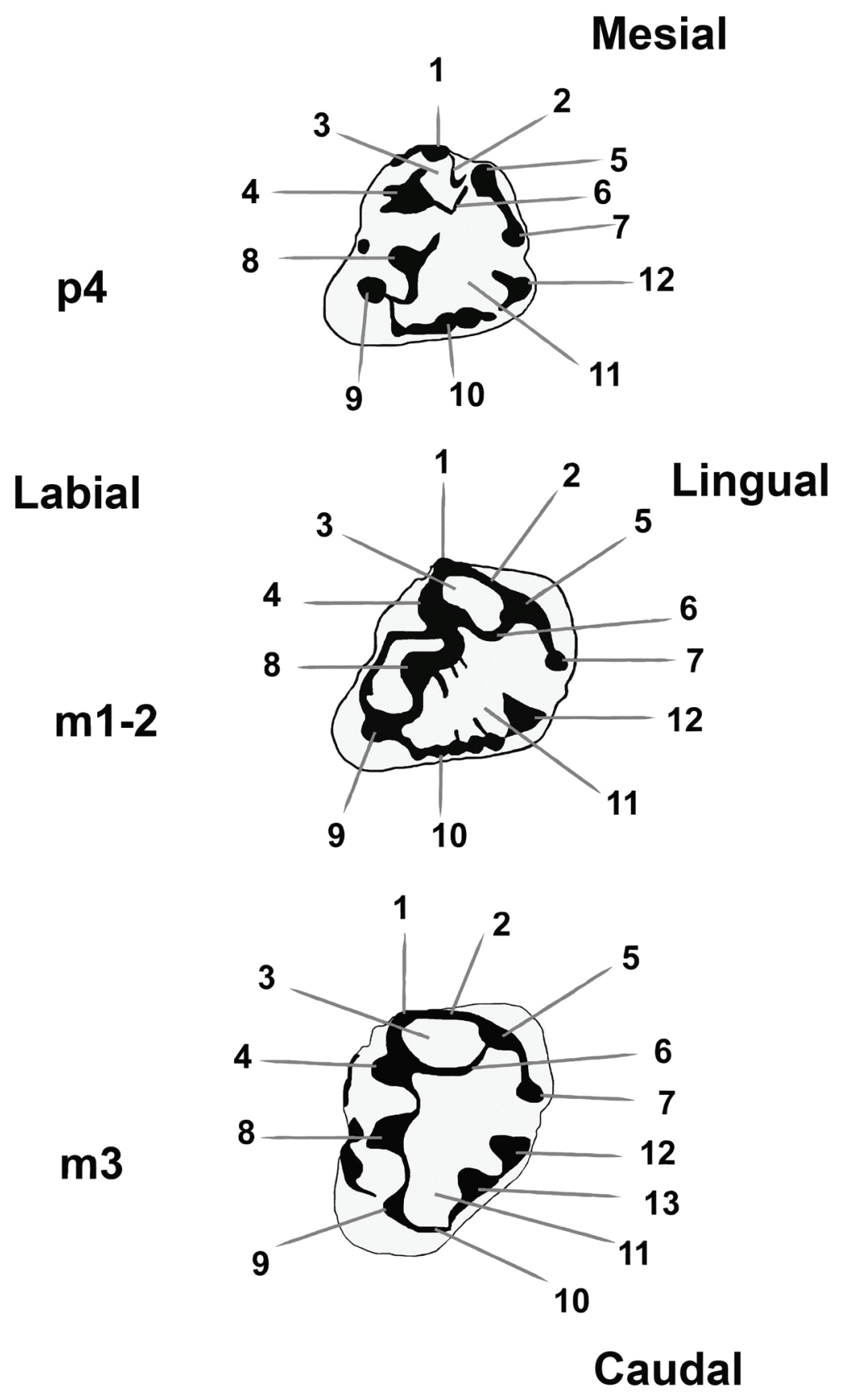

Fig. 2. Morphological nomenclature of Albanensia lower p4, m1-2, m3 (after Cuenca Bescos 1988; DAXNER-HÖCK 2004, 2010). 1 = anteroconulid; 2 = anterolophid; 3 = trigonid basin; $4=$ protoconid; $5=$ metaconid; $6=$ metalophid; $7=$ mesolophid; $8=$ mesoconid; $9=$ hypoconid; $10=$ posterolophid; $11=$ talonid basin; 12 = entoconid; $13=$ hypoconulid 
Höck 2004). These ridges are converged to the labial side of the protocone in $\mathrm{V}$-shape. Protoconule is not a distinct cusp, it is incorporated into the protoloph. Mesostyle crista is not developed. Mesostyle is a small distinct cusp in the labial margin of the central sinus. Metaconule is present. The lingual surface of the protocone is not rugose, and the two impressions and the cingulum - which are characteristic elements in the lingual side of P4-M1-2 in the more evolved Albanensia species - are absent. Posteroloph is a thin continuous ridge. There are three roots.

M1-2 - It has subrectangular outline with rounded lingual side because of the convex lingual wall of the protocone. Width of the crown is larger than the length. Anteroloph is developed as a continuous ridge on the mesial margin of the crown between the protocone and the anterior base of the paracone. This ridge is without minor cusps. Protoloph and metaloph converge to the labial side of the protocone in V-shape. Protoconule is incipient. Protoloph is a continuous ridge between the protocone and the paracone. It does not form a "zigzag line". The mesostyle crista on the posterior side of the paracone is underdeveloped. The mesostyle is a small, but distinct cusp. The metaloph connects the protocone, metaconule, and metacone. A secondary ridge starts from the metacone to the posteroloph. The metaconule has a large posterior ledge, but it does not reach the posteroloph. Hypocone is incipient. Posteroloph is thinner and lower developed than the other main ridges.

M3 - It has subtriangular outline with rounded angles. Anteroloph and protoloph are nearly parallel. Protoconule, mesostyle, and mesostyle crista are absent. Metaloph is a short, curved ridge between the posterior side of the protocone and the postero-lingual part of the posteroloph. Secondary ridges are absent.

Figs 3-25. Occlusal surfaces of Albanensia teeth from the studied localities. - Fig. 3. A. sansaniensis, P4, Szentendre, MMP.2019.722. - Fig. 4. A. grimmi, P4, Rudabánya, MGSH V.25724. - Fig. 5. A. grimmi, P4, Felsőtárkány 3/2, MMP.2003.432. - Fig. 6. A. albanensis, M1, Mikófalva, MMP.2019.1157. - Fig. 7. A. sansaniensis, M1-2, Szentendre, MMP.2018.431. - Fig. 8. A. grimmi, M1, Felsőtárkány 3/2, MMP.2003.437. - Fig. 9. A. grimmi, M1, Rudabánya, MGSH V.25729. Fig. 10. A. sansaniensis, p4, Szentendre, MMP.2018.434. - Fig. 11. A. sansaniensis, M3, Szentendre, MMP.2019.688. - Fig. 12. A. grimmi, M3, Felsőtárkány 3/2, MMP.2003.438. - Fig. 13. A. grimmi, M3, Rudabánya, MGSH V.25734. - Fig. 14. A. grimmi, p4, Felsőtárkány 3/2, MMP.2003.442. Fig. 15. A. sansaniensis, m1, Szentendre, MMP.2018.435. - Fig. 16. A. grimmi, m1, Rudabánya, MGSH V.25719. - Fig. 17. A. albanensis, m1, Mikófalva, MMP.2019.1158. - Fig. 18. A. grimmi, p4, Rudabánya, MGSH V.24374. - Fig. 19. A. sansaniensis, m2, Szentendre, MMP.2018.437. - Fig. 20. A. grimmi, m1, Felsőtárkány 3/2, MMP.2003.445. - Fig. 21. A. grimmi, m2, Rudabánya, MGSH V.24376. - Fig. 22. A. grimmi, m2, Felsőtárkány 3/2, MMP.2003.446. - Fig. 23. A. sansaniensis, m3, Szentendre, MMP.2019.727. - Fig. 24. A. grimmi, m3, Felsőtárkány 3/2, MMP.2003.441. - Fig. 25. A. grimmi, m3, Rudabánya, MGSH V.24377 


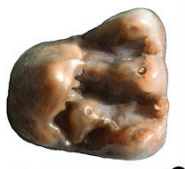

3

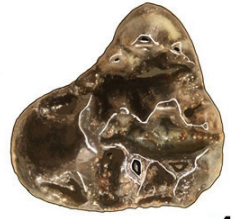

4

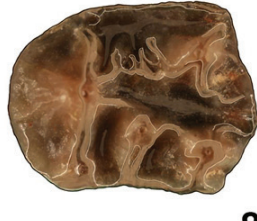

8

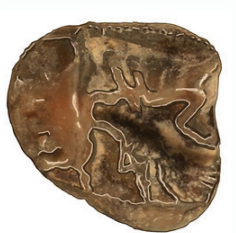

12

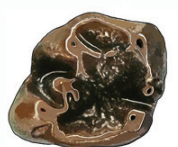

15

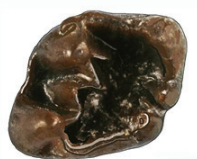

19

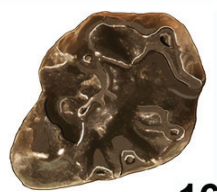

16

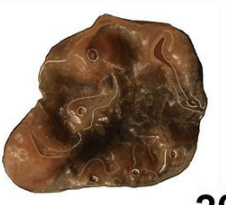

20

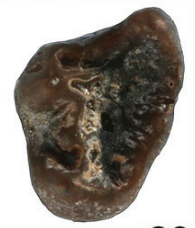

23

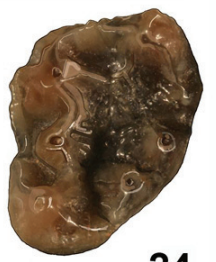

24
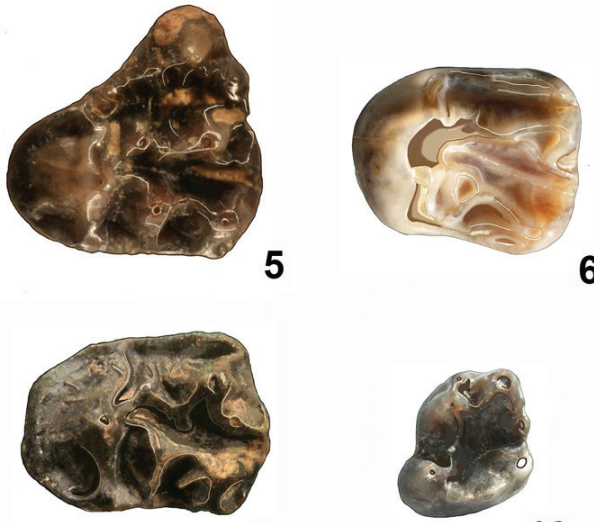

9

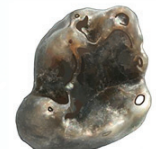

10
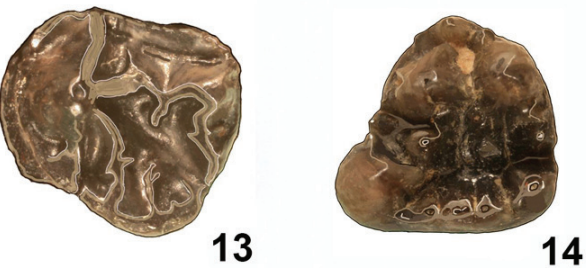

13
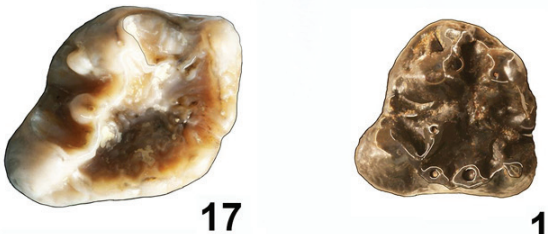

18
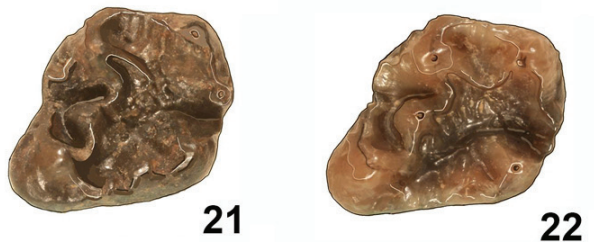

$1 \mathrm{~mm}$

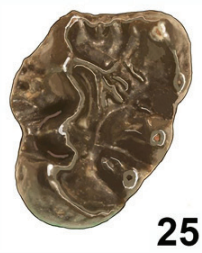


$d 4$ - It has trapezoidal outline with rounded angles. Anterior width is narrower than the posterior one. The greatest part of the occlusal surface is occupied by a large talonid basin. The cusps are definitely smaller than the cusps of the permanent molars. Protoconid and the metaconid are situated in the mesial surface. They are close to each other. In the postero-labial angle the hypoconid is developed. The entoconid is incorporated into the posterolophid. Mesoconid is a low-developed cuspula between the protoconid and the hypoconid. There is an incision between the hypoconid and the metaconid in the lingual margin.

$p 4$ - It has trapezoidal outline with rounded angles. Anterior margin is narrower than the posterior one. Three cusps are developed on the mesial part of the crown: the well-developed protoconid, metaconid, and a lower developed anteroconulid. A narrow trigonid basin is closed by these three cusps. Anteroconulid and metaconid are connected by a narrow anterolophid. The V-shaped metalophid is developed on the posterior slope of the protoconid and metaconid. An enamel ridge is developed on the posterior slope of the metaconid reaching to the mesolophid. It is less expressed than the same structure in A. grimmi. The mesoconid is a low developed cuspula. The C-shaped basin between the mesoconid and the labial margin (which is found in A. grimmi) is not developed. Mesoconid is connected to the base of the protoconid and hypoconid by enamel ridges. The posterolophid is a continuous ridge between the hypoconid and the entoconid. It is not dissected by minor cusps, which is visible in the posterolophid of $A$. albanensis and A. grimmi lower teeth. A deep and wide incision is found between the entoconid and mesolophid. The surface of the talonid basin is not complicated by secondary ridges and crenulation. There are two roots.

m1-2 - Rhomboidal outline. In comparison with the $\mathrm{p} 4$ the anterior margin is wider. A strong anterolophid is extending on the mesial margin between the protoconid and the metaconid. These two ridges are connected by the lower developed metalophid too. This metalophid is straight, transversal and not $\mathrm{V}$-shaped (the V-shaped metalophid is visible in A. grimmi lower molars). A trigonid basin is rounded by the protoconid-metaconid-anterolophid-metalophid system. An enamel ridge is developed on the posterior slope of the metaconid reaching to the mesolophid. There is a closed C-shaped basin between the labial cingulum and the mesoconid. The posterolophid is a continuous ridge between the hypoconid and the entoconid. It is not dissected by minor cusps. There is a deep and narrow incision between the mesolophid and the entoconid. The surface of the central basin is complicated by secondary ridges and crenulation, but these ridges are less developed than those in $A$. albanensis and $A$. grimmi. Four roots.

$m 3$ - The general structure is similar to the crown of $m 1-2$. The differences are as follows: more elongated rhomboid outline, because of the anteriorly pro- 
longed metaconid. No closed basin on the labial side of the mesoconid, since the labial cingulum is weaker than that in $A$. albanensis and $A$. grimmi. Hypoconulid is not developed. Four roots.

Remarks - The classification of the finds is based on the small dimensions and the morphology. Up to the present $A$. sansaniensis has not been reported from Hungary. After Ginsburg \& Mein (2012) A. sansaniensis differs from $A$. albanensis in the following morphological characters: smaller dimensions, more simple parastyle in the upper molars, and the absence of hypoconulid in the lower molars. In the Szentendre material there are some additional morphological features: the two impressions and the cingulum on the lingual surface of the P4 and M1-2 are absent, the mesostyle crista is underdeveloped or absent, mesostyle is a distinct small cusp in P4 and in M1-2, posteroloph is a continuous ridge, which is not a "string of pearls". The secondary ridges and the crenulation of the enamel surface are less developed than the same structures in the more evolved Albanensia species. In strongly worn elder specimen those have not been preserved.

The earliest occurrences of $A$. sansaniensis are reported from the Early Miocene (MN 4) faunas of Spain: Montalvos 2, Calatayud-Teruel Basin (HordIJ et al. 2015), and Barranco del Candel, near Buñol (Adrover 1987). Among the Albanensia species $A$. sansaniensis is unambiguously the smallest one (Figs 26, 27). The geographical range of $A$. sansaniensis reached up to Anatolia, because it was reported from the MN5 fauna of Çandir (DE BRUIJN et al. 2003).

The elaboration of the recently collected new fauna from Szentendre is in progress. From the biochronological point of view the most important element of this assemblage is Cricetodon aureus, which is a characteristic species of the early MN6 faunas of Southern Germany, Switzerland, and France (ABDUL-AzIZ et al. 2008; HeIssig 2006; KÄLIN \& KeMPF 2009).

\section{Albanensia sp. 1}

(Table 2)

Locality - Subpiatră/Kőalja 2/3.

Material -

Table 2. Individual data of Albanensia sp. tooth from Subpiatră/Kőalja

\begin{tabular}{lcccc}
\hline Locality & Work no. & Position & L & W \\
\hline Subpiatră $2 / 3$ & $6 / 5$ & D4 & 2.90 & 3.00 \\
\hline
\end{tabular}

Morphological description - D4 - Subtriangular outline. Anterolophid and parastyle are protuberant. Protoloph and metaloph converge to the protocone 
in V-shape. The cusps metacone, metaconule, and protocone are stringed by the metaloph. Small irregular secondary ridges start from these three cusps to the posteroloph. Mesolophid is developed as a minor cusp and connected to the entoconid. The upper premolar from Subpiatră is much smaller than the P4 from Tauț. Not having permanent molars the find is not sufficient for a classification on the species level.

Remarks - Hír et al. (2016) classified the Subpiatră/Köalja localities to the transition of the middle Badenian and late Badenian without correlation of the $\mathrm{MN}$ zones. Useful elements for the establishment of the biochronological classification are Muscardinus aff. thaleri, the relatively small-sized Democricetodon brevis, Megacricetodon similis (only occurrence in the Carpathian Basin). In Switzerland the coexistence of Megacricetodon similis and Democricetodon brevis is experienced in the latest MN6 and early MN7/8 biozones (KäLIN \& KEMPF 2009). In our present view the most probable biochronological position of the Subpiatră/Köalja Miocene palaeovertebrate localities is late Badenian, MN6.

\section{Albanensia sp. 2}

(Table 3)

2015 A. albanensis (Major, 1893) - Hír, p. 332.

2019 Albanensia sp. - Hír et al., p. 6.

Locality - Kozárd.

Material -

Table 3. Individual data of the Albanensia tooth from Kozárd

\begin{tabular}{lccccc}
\hline Locality & No. inv. MMP & Position & L & W & Published figures \\
\hline Kozárd & 2016.9. & $\mathrm{~m} 3$ & 4.40 & 3.67 & Hír 2015: Fig. 3/1; Hín et al. 2019: \\
& & & & Fig. 29f \\
\hline
\end{tabular}

Morphological description - m3 - Juvenile molar with fragmented metaconid. The description and the figures are given in the cited publications. The material is fragmentary, inadequate for exact species determination.

Remarks - The locality is situated in the type section of the Kozárd Formation (HÁmoR 1985). Hámor classified the Sarmatian coastal and shallow marine sediments as members of the unit. The limestones, calcareous sands, and marls of the Kozárd section are extremely rich in fossil molluscs. This malacofauna was investigated by BODA $(1959,1974)$, and foraminifers were studied by То́тн \& Csома (2015). They classified the assemblage in the early Sarmatian Elphidium reginum Zone. The microvertebrate material is referred to the MN7+8 Zone (Hír 2016; Hír et al. 2019). 


\section{Albanensia albanensis (Major, 1893)}

(Figs 6, 17, Table 4)

Locality - Mikófalva.

Material -

Table 4. Individual data of the Albanensia teeth from Mikófalva

\begin{tabular}{lccccc}
\hline Locality & No. inv. MMP & Position & L & W & Figures in the present paper \\
\hline Mikófalva & 2019.1157. & M1 & 3.30 & 4.07 & Fig. 6 \\
Mikófalva & 2019.1158. & m1 & 3.62 & 3.60 & Fig. 17 \\
\hline
\end{tabular}

Morphological description - M1 - It has rectangular outline with rounded lingual side. The anteroloph developed as a continuous ridge on the mesial margin of the crown. Protoloph and metaloph converge to the labial side of the protocone in V-shape. These two ridges are straight (not "zigzag-shaped"). Protoloph connects the paracone and a smaller protoconule. An arched mesostyle crista starts from the paracone to labial direction. Mesostyle is absent. Secondary ridges are not found in the central sinus. The metaloph connects the metacone and the welldeveloped metaconule. Two secondary ridges reach from the metacone and metaconule to the posteroloph across the posterosinus. The two impressions on the convex lingual surface of the protocone are weak. Lingual cingulum on the base of the protocone is absent. The posteroloph is thin and lower developed than the other main ridges. The hypocone is developed as an enamel islet. Three roots.

$m 1$ - There is a strong, arched anterolophid on the mesial margin between the protoconid and the metaconid. Metalophid is weaker and only its labial part is well-developed. The protoconid has a labial ledge. Mesoconid is lower developed than the protoconid and the hypoconid. The C-shaped basin in the labial side of the mesoconid is sharply developed, but the labial cingulum (which is characteristic in $A$. grimmi) is absent. There is an impression on the posterior side of the hypoconid. The straight posteroloph runs between the hypoconid and the small entoconid. There is a notch between the entoconid and the mesolophid. The trigonid, and the talonid basins are sculptured by irregular secondary ridges.

Remarks - The dimensions of the finds from Mikófalva are definitely larger than those of the corresponding molars of $A$. sansaniensis. The following morphological characters differ from $A$. grimmi: the straight protoloph and metaloph, the absence of impressions and cingulum in the lingual surface of $M 1$, the absence of labial cingulum, and the presence of continuous posterolophid without minor conids in $\mathrm{m} 1$.

The surroundings of the village Mikófalva is memorable in the Hungarian palaeontological literature, because of the occurrences of well-preserved silicified 
trunks (ANDREÁNSZKY 1956). A field trip was organized by the author in April, 2018 with the voluntary help of Dr. Árpád Dávid and Ms. Rozália Fodor museologists. A $100 \mathrm{~kg}$ test sample was taken from the deep trench, named as "Özikegödör", which is situated $1 \mathrm{~km} \mathrm{SW}$ from the village. It was first described by DÉR (1957), who mentioned the alternately bedded fluviatile sand and rhyolitic tuff layers, which are exposed in the trench. The sampled sediment is grey-coloured sand. This fluviatile sediment is merged with the Felnémet Rhyolite Tuff Formation by the mapping geologists (PELIKÁN 2005). Only the two Albanensia molars were found in the sample.

Some sporadic palaeovertebrate finds and the faunula from Egerbocs (Hí 2001) were excavated from the freshwater sediments in the NW foothill region of the Bükk Mountains. These materials were not sufficient for biochronological conclusions, but based on the new Albanensia albanensis molars we can presume the Sarmatian age and the MN7+8 Zone.

\section{Albanensia sp. 3}

(Table 5)

?2011 Albanensia sp. - Hír et al., p. 217.

Locality - Tauț/Feltót.

Material -

Table 5. Individual data of the Albanensia teeth from Tauț/Feltót

\begin{tabular}{lccccc}
\hline Locality & No. Inv. ISER & Position & L & W & Published figures \\
\hline Tauț & Tt $0132 / 1$ & D4 & 3.42 & 3.47 & HíR et al. 2011: fig. 1, 3 \\
Tauț & Tt $0132 / 2$ & d4 & 3.02 & 2.5 & HíR et al. 2011: fig. 1, 1 \\
\hline
\end{tabular}

Morphological description - D4 - The outline of the occlusal surface is triangular. Parastyle is protuberant. The transversal ridges (anteroloph, protoloph, metaloph, posteroloph) are all connected to the protocone. The cusps paracone and metacone are incorporated into the protoloph and metaloph. The two ridges slightly converge to the protocone and are crenulated.

$d 4$ - It has trapezoidal outline, posterior margin is wider than the anterior one. The strongest cusp is the metaconid. Protoconid and metaconid are separated by a narrow trench. A mesial ridge merges from the protoconid. On the posterior side of the protoconid there is a branched sculpture. Mesoconid is low and has a strong connection to the protoconid and the hypoconid. Mesolophid is developed as a small rounded cusp. 
Remarks - The microvertebrate material of Tauț/Feltót was first described by FERU et al. (1979). Based on the evolutionary stage of the cricetid finds RĂDULESCU \& SAMSON (1988) suggested a Volhynian (early Sarmatian) correlation for this locality and assigned the fauna to the MN8 Zone. Hír et al. (2011) revised the material and classified it as late Sarmatian with special MN9 affinities of some taxa (Hír et al.2017).

\section{Albanensia sp. 4}

2006 Albanensia sp. - Hír, p. 158.

Locality - Felsőtárkány-Felnémet 2/3.

The data and the description of the fragmented material are given in Hí $R$ (2006). It is not sufficient for a definitive species determination.

Remarks - The section is found at the side of the road between Felnémet and Felsötárkány. The two faunas of the section (FF $2 / 3$ and FF 2/7) are slightly older than the faunas of the section of Felsötárkány "Güdör-kert". FF 2/3 is the type locality of "Cricetodon" klariankae, which is the last occurrence of cricetodontini in the Carpathian Basin. The biochronological position of the fauna was classified as MN7+8 Zone, late Sarmatian (Hír 2006; Hír et al. 2016, 2017).

\section{Albanensia sp. 5}

2010 Albanensia sp. - Hí R, pp. 216-217, fig. 1.

2011 Albanensia sp. - Hír \& KóKaY, p. 71, fig. 6-1.

Locality - Mátraszőlős 3.

The material is a posterior fragment of an upper deciduous premolar. Description is given by Hír \& Kó KAY (2011). The fragmentary material is inadequate for exact species determination.

Remarks - Three microvertebrate localities were sampled in the northern foreland of the village (Hír \& KóKAY 2004, 2011). All of them produced rich nonmarine mollusc fauna, which have late Badenian affinities. The rodent material can be classified as MN7+8 Zone, because of the presence of Democricetodon brevis and Democricetodon freisingensis.

Albanensia grimmi (Black, 1966)

(Figs 5, 8, 12, 14, 20, 22, 24, Table 6)

2003 Albanensia grimmi (Black, 1966) - Hír, pp. 125-136, Plate II. figs 1-6.

Locality - Felsőtárkány 3/2. 
Material -

Table 6. Individual data of the Albanensia teeth from Felsőtárkány 3/2

\begin{tabular}{lcccccc}
\hline Locality & $\begin{array}{c}\text { No. inv. } \\
\text { MMP }\end{array}$ & Position & L & W & Published figures & $\begin{array}{c}\text { Figures in } \\
\text { present paper }\end{array}$ \\
\hline Felsőtárkány 3/2 & 2015.385. & $\mathrm{D} 4$ & 3.2 & 3.45 & & \\
Felsőtárkány 3/2 & 2003.430. & $\mathrm{P} 3$ & 1.50 & 2.00 & & \\
Felsőtárkány 3/2 & 2003.431. & $\mathrm{P} 3$ & 1.60 & 1.90 & & \\
Felsőtárkány 3/2 & 2003.432. & $\mathrm{P} 4$ & 4.32 & 4.50 & HíR 2003: Pl. II: 2 & Fig. 5 \\
Felsőtárkány 3/2 & 2003.433. & $\mathrm{M} 1-2$ & 3.62 & 4.27 & & \\
Felsőtárkány 3/2 & 2003.434. & $\mathrm{M} 1-2$ & 3.57 & 4.37 & & \\
Felsőtárkány 3/2 & 2003.435. & $\mathrm{M} 1-2$ & 3.37 & 4.36 & HíR 2003: Pl. II: 4 & \\
Felsőtárkány 3/2 & 2003.436. & $\mathrm{P} 4 \mathrm{fragm}$. & - & 4.50 & & \\
Felsőtárkány 3/2 & 2003.437. & $\mathrm{M} 1-2$ & 3.30 & 4.25 & & Fig. 8 \\
Felsőtárkány 3/2 & 2003.438. & $\mathrm{M} 3$ & 3.80 & 4.10 & HíR 2003: Pl. II: 6 & Fig. 12 \\
Felsőtárkány 3/2 & 2003.439. & $\mathrm{M} 3$ & 3.88 & 3.88 & & \\
Felsőtárkány 3/2 & 2003.442. & $\mathrm{p} 4$ & 3.80 & 4.0 & & Fig. 14 \\
Felsőtárkány 3/2 & 2003.443. & $\mathrm{p} 4$ & 3.67 & 3.82 & HíR 2003: Pl. II: 1 & \\
Felsőtárkány 3/2 & 2003.444. & $\mathrm{~m} 1$ & 3.37 & 3.92 & HíR 2003: Pl. II: 3 & \\
Felsőtárkány 3/2 & 2003.445. & $\mathrm{~m} 1$ & 3.42 & 4.05 & & Fig. 20 \\
Felsőtárkány 3/2 & 2003.446. & $\mathrm{~m} 2$ & 3.62 & 4.12 & & Fig. 22 \\
Felsőtárkány 3/2 & 2003.447. & $\mathrm{~m} 2$ & 3.55 & 4.25 & & \\
Felsőtárkány 3/2 & 2003.440. & $\mathrm{~m} 3$ & 4.37 & 3.80 & HíR 2003: Pl. II: 5 & \\
Felsőtárkány 3/2 & 2003.441. & $\mathrm{~m} 3$ & 4.47 & 3.75 & & Fig. 24 \\
\hline & & & & & & \\
\hline
\end{tabular}

Morphological description - P3 - It has unicuspid tooth having one root. The outline of the crown is elliptic. There is a wedge-like incision in the posterior side of the cusp.

D4 - It has subtriangular outline with rounded angles. The morphology is generally similar to the crown of $\mathrm{P} 4$, the differences are the followings: less developed cusps and secondary ridges, the anterior arm of the metacone and the mesostyle crista are fused.

P4 - It has subtriangular outline with rounded angles. Parastyle and anteroloph are protuberant and wear a small additional cusp on the labial side of the parastyle (anteroconule in the interpretation of KRETzOI \& FEJFAR 2004). Secondary ridges start from the parastyle to the anterosinus. Anteroloph, protoloph, and metaloph can be considered as a series of well-developed cusps rather than simple ridges. Because of the cusps the protoloph and metaloph form "zigzag" crests (in the interpretation of DAXNER-HöCK 2004). These main ridges converge to the 
labial side of the protocone forming a V-shape. Protoloph wears a well-developed paracone and a smaller protoconule. An arched mesostyle crista start from the paracone to labial direction. Secondary ridges start from the protoconule and the paracone into the anterosinus. The secondary ridges directed to the central sinus are shorter. Metaloph bears a metacone and metaconule. The hypocone is small. The posterosinus is not a continuous trench because it is interrupted by longitudinal secondary ridges starting from the metacone and metaconule. There are two strong impressions on the convex lingual surface of the protocone and a cingulum on its base. This cingulum is formed by a series of minor cusps. Three roots.

M1-2 - It has rectangular outline with rounded lingual side. The anteroloph is developed as a continuous ridge on the mesial margin of the crown. It does not wear cusps. Protoloph and metaloph converge to the labial side of the protocone in V-shape. Protoloph connects the paracone and a smaller protoconule in "zigzag" line. An arched mesostyle crista start from the paracone to labial direction. Secondary ridges are not found in the central sinus. The metaloph connects the metacone and the metaconule in zigzag line. Two secondary ridges reach from the metacone and metaconule to the posteroloph across the posterosinus. There are two impressions on the convex lingual surface of the protocone. Its lingual surface wears a cingulum, which is formed by a row of minor cusps. The posteroloph is thinner and lower developed than the other main ridges. The small hypocone is developed in a lower level. Three roots.

M3 - It has triangular outline with rounded angles. The anteroloph is developed as a continuous ridge on the mesial margin of the crown without cusps. Protoconule is less developed than the same cuspula in M1-2. The paracone mesostyle crista is well-developed. There are the cingulum on the lingual surface of the protocone and an anterior impression. Metaloph is directed posteriorly and run to the posteroloph. The central sinus is directed posterolabially. Its surface is complicated by secondary ridges. Three roots.

$p 4$ - It has trapezoidal outline with rounded angles. Anterior margin is narrower than the posterior one. Three cusps are developed on the mesial part of the crown: the well-developed protoconid and metaconid and a lower developed anteroconulid. A narrow trigonid basin is bordered by these three cusps. Anteroconulid and metaconid are connected by a narrow anterolophid. The $\mathrm{V}$-shaped metalophid is developed on the posterior slope of the protoconid and metaconid. A strong enamel ridge is developed on the posterior slope of the metaconid reaching to the mesolophid. The mesoconid is a low developed cuspula which is divided from the labial margin by a trench. Mesoconid is connected to the base of the protoconid and hypoconid by enamel ridges. The posterolophid consists of three fused minor cusps like a row of pearls. There is a shallow incision of the posterolophid and the entoconid. A deep and wide incision is found 
between the entoconid and mesolophid. The surface of the talonid basin is complicated by secondary ridges and crenulation. The tooth is two rooted but the wide posterior root is the result of the fusion of two roots.

m1-2 - It has rhomboidal outline. Related to the p4 the anterior margin is wider. A strong anterolophid is extending on the mesial margin between the protoconid and the metaconid. These two ridges are connected by the V-shaped metalophid too. A trigonid basin is rounded by the protoconid-metaconid-anterolophidmetalophid system. A strong enamel ridge is developed on the posterior slope of the metaconid reaching to the mesolophid. There is a closed C-shaped basin between the labial cingulum and the mesoconid. The posterolophid consists of three fused minor cusps like a row of pearls. No incision in the labial side of the entoconid, but a deep incision is found between the entoconid and the mesolophid. The surface of the talonid basin is complicated by secondary ridges and crenulation. Four roots.

$m 3$ - The general structure is similar to the crown of $m 1-2$. The differences are the followings: more elongated rhomboid outline, metalophid is not $\mathrm{V}$-shaped but it is nearly horizontal, no closed basin on the labial side of the mesoconid, because the labial cingulum is not so strong, the lingual part of the posterolophid consists of two strong cusps: the entoconid and the hypoconulid. Four roots.

Remarks - Felsőtárkány $3 / 2$ is the richest microvertebrate fauna of the Felsötárkány Basin. It contains four flying squirrel genera: Albanensia, Miopetaurista, Neopetes and Blackia. The dominant rodent is Collimys dobosi Hír, 2005. The biochronological position is late MN7+8 Zone (HÍr 2003; Hír et al. 2016, 2017).

Albanensia grimmi (Black, 1966)

(Figs 4, 9, 13, 16, 18, 21, 25, Table 7)

partim 1976 Miopetaurista cf. albanensis (Gaillard, 1899) - KRETzor et al., p. 375.

2004 Albanensia grimmi (Black, 1966) - KREtzor \& FejfAR, pp. 119-122, Text-figs 10, 1.

Locality - Rudabánya.

Kretzor \& Fejfar (2004) gave a detailed morphological description of the Albanensia material from Rudabánya (which is the richest assemblage of the genus in Europe). However, numeric data of the measurements are absent, only scatter diagrams are published in Text-fig. 11, and the gathering of the exact data from these diagrams is difficult.

In 2015 the author studied the Albanensia material from Rudabánya, which is stored in the Collection of the Mining and Geological Survey of Hungary (earlier Hungarian Geological Institute). The main goals of this reinvestigation were: the repeated measuring of the molars, and the morphological comparison of the Albanensia materials of Felsőtárkány 3/2 and Rudabánya. The results are given in Tables 7-8. 
Table 7. Individual data of the Albanensia grimmi molars from Rudabánya stored in the Museum of the Mining and Geological Survey of Hungary

\begin{tabular}{|c|c|c|c|c|c|}
\hline Locality & No. inv. MGSH & Position & $\mathrm{L}$ & $\mathrm{W}$ & Figures in the present paper \\
\hline Rudabánya & V.24368. & P3 & 1.60 & 1.80 & \\
\hline Rudabánya & V.24369. & P3 & 1.52 & 1.77 & \\
\hline Rudabánya & V.25726. & P3 & 1.47 & 1.77 & \\
\hline Rudabánya & V.25727. & P3 & 1.52 & 1.77 & \\
\hline Rudabánya & 802 & P4 & 3.62 & 3.72 & \\
\hline Rudabánya & V.25724. & P4 & 3.72 & 3.85 & Fig. 4 \\
\hline Rudabánya & V.25725. & P4 & 3.52 & 4.0 & \\
\hline Rudabánya & V.06.1481. & $\mathrm{P} 4$ & 3.52 & 4.0 & \\
\hline Rudabánya & V.25728. & M1 & 2.90 & 3.97 & \\
\hline Rudabánya & V.25729. & M1 & 2.92 & 4.0 & Fig. 9 \\
\hline Rudabánya & V.25731. & M1 & 2.90 & 3.77 & \\
\hline Rudabánya & V.25732. & M1 & 2.95 & 3.75 & \\
\hline Rudabánya & V.25732. & M1 & 2.95 & 4.0 & \\
\hline Rudabánya & V.06.1481. & M1 & 2.95 & 4.0 & \\
\hline Rudabánya & V.24371. & M2 & 3.47 & 4.37 & \\
\hline Rudabánya & V.25733. & M2 & 3.12 & 3.87 & \\
\hline Rudabánya & V.25734. & M2 & 3.20 & 3.77 & Fig. 13 \\
\hline Rudabánya & V.25735. & M2 & 3.15 & 3.80 & \\
\hline Rudabánya & V.25736. & M2 & 3.07 & 3.87 & \\
\hline Rudabánya & V.25730. & M2 & 2.87 & 3.77 & \\
\hline Rudabánya & V.06.1481. & M2 & 3.22 & 4.05 & \\
\hline Rudabánya & V.25737. & M3 & 3.50 & 3.75 & \\
\hline Rudabánya & V.25738. & M3 & 3.22 & 3.50 & \\
\hline Rudabánya & V.25328. & M3 & 3.42 & 3.65 & \\
\hline Rudabánya & V.06.1481. & M3 & 3.42 & 3.65 & \\
\hline Rudabánya & V.24372. & $\mathrm{d} 4$ & 2.77 & 2.60 & \\
\hline Rudabánya & V.24373. & $\mathrm{d} 4$ & 2.45 & 2.30 & \\
\hline Rudabánya & V.24374. & $\mathrm{p} 4$ & 3.32 & 3.25 & Fig. 18 \\
\hline Rudabánya & V.24375. & $\mathrm{p} 4$ & 3.17 & 3.32 & \\
\hline Rudabánya & V.25717. & $\mathrm{p} 4$ & 3.32 & 3.15 & \\
\hline Rudabánya & V.25718. & $\mathrm{p} 4$ & 3.12 & 3.0 & \\
\hline Rudabánya & V.25719. & $\mathrm{m} 1$ & 3.37 & 3.62 & Fig. 16 \\
\hline Rudabánya & V.25721. & $\mathrm{m} 1$ & 3.47 & 3.55 & \\
\hline Rudabánya & V.25720. & $\mathrm{m} 2$ & 3.70 & 3.50 & \\
\hline Rudabánya & V.25722. & $\mathrm{m} 2$ & 3.57 & 3.50 & \\
\hline Rudabánya & V.24376. & $\mathrm{m} 2$ & 3.80 & 3.77 & Fig. 21 \\
\hline Rudabánya & V.25723. & $\mathrm{m} 3$ & 4.12 & 3.50 & \\
\hline Rudabánya & V.24377. & $\mathrm{m} 3$ & 4.05 & 3.35 & Fig. 25 \\
\hline
\end{tabular}


Table 8. A morphological comparison of the Albanensia grimmi teeth from Felsőtárkány $3 / 2$ and Rudabánya

\begin{tabular}{lcc}
\hline Position & Felsötárkány 3/2 & Rudabánya \\
\hline P4 & $\begin{array}{c}\text { Well-developed distinct cusp on the la- } \\
\text { bial side of the broad parastile (Fig. 5) }\end{array}$ & $\begin{array}{c}\text { Very weekly developed cusp on the } \\
\text { labial side of the parastyle, the parastyle } \\
\text { is narrower (Fig. 4) }\end{array}$ \\
M1-2 & $\begin{array}{c}\text { Protoconule is relatively small. No } \\
\text { accessory ridge which is directed into } \\
\text { the central sinus from the protoloph } \\
\text { (Fig. 8) }\end{array}$ & $\begin{array}{c}\text { Protoconule is relatively larger. A strong } \\
\text { accessory ridge directed into the central } \\
\text { sinus from the protoloph between the } \\
\text { protoconule and the paracone (Fig. 9) }\end{array}$ \\
p4 & $\begin{array}{c}\text { Strong roots. The metaloph directed } \\
\text { diagonally (Fig. 12) }\end{array}$ & $\begin{array}{c}\text { Narrower roots. The metaloph directed } \\
\text { posteriorly (Fig. 13) }\end{array}$ \\
m1 & No morphological difference (Fig. 14) & $\begin{array}{c}\text { No morphological difference (Fig. 18) } \\
\text { m2 }\end{array}$ \\
No morphological difference (Fig. 20) & $\begin{array}{c}\text { No morphological difference (Fig. 16) } \\
\text { Metalophid well developed, continu- } \\
\text { ous (Fig. 22) }\end{array}$ & $\begin{array}{c}\text { Metalophid not always continuous, fre- } \\
\text { quently incorporated into the posterior } \\
\text { slope of the metaconid (Fig. 21) }\end{array}$ \\
m3 & No morphological difference (Fig. 24) & No morphological difference (Fig. 25) \\
\hline
\end{tabular}

Remarks - Consequent time transgressive magnification of the dimensions is not found when we compare the $A$. albanensis and $A$. grimmi finds collected from the faunas of the MN7+8 and MN9 Zones (Figs 26, 27). Moreover the $A$. grimmi $\mathrm{P} 4, \mathrm{M} 3, \mathrm{p} 4, \mathrm{~m} 1, \mathrm{~m} 2$ from Felsötárkány $3 / 2$ (late MN7/8) are definitely larger than the corresponding $A$. grimmi teeth from Rudabánya (MN9). The dimensions of the latter population are closer to those of $A$. albanensis from Gratkorn (Figs 26,27). The numeric age of Felsőtárkány $3 / 2$ is estimated as $12.2-$ 11.6 MY (Hír et al. 2017), the numeric age of Rudabánya is estimated between 11.1-9.7 MY (HOWELL 2004).

DAXNER-Höck (2004) classified the differences between the two Albanensia species: " $A$. grimmi differs from $A$. albanensis by the pronounced protoconule and metaconule of P4-M2; the zigzag-shaped protoloph and metaloph of P4M2; the large P4; the dominant hypoconulid of p4-m3; the relatively short m3". Later DAXNER-HöcK (2010) defined the distinctive characters of $A$. albanensis as follows: smaller dimensions, lower and less-crenulated loph(id)s and con(id)s, smaller $\mathrm{P} 4 / \mathrm{p} 4$, longer $\mathrm{m} 3$ with continuous posterolophid and a small or absent hypoconulid, straight (not zigzag-shaped) protoloph and metaloph, absent or very short protoconule, small hypocone.

Based on the above listed criteria the classification of the Rudabánya population is confuse, because the first and third criteria (smaller dimensions, smaller P4/p4) are adequate for this material. The small mean dimensions of the 
Rudabánya population is difficult to interpret (Figs 26-27). Possible explanations are as follows: the available material is limited and the real intraspecific metric variation is not represented; or we can presume more evolutionary lines inside the species $A$. grimmi.

\section{DISCUSSION}

Three species of the Albanensia genus are represented in the fossil record of the Carpathian region: A. sansaniensis, A. albanensis, and A.grimmi. A. sansanien-

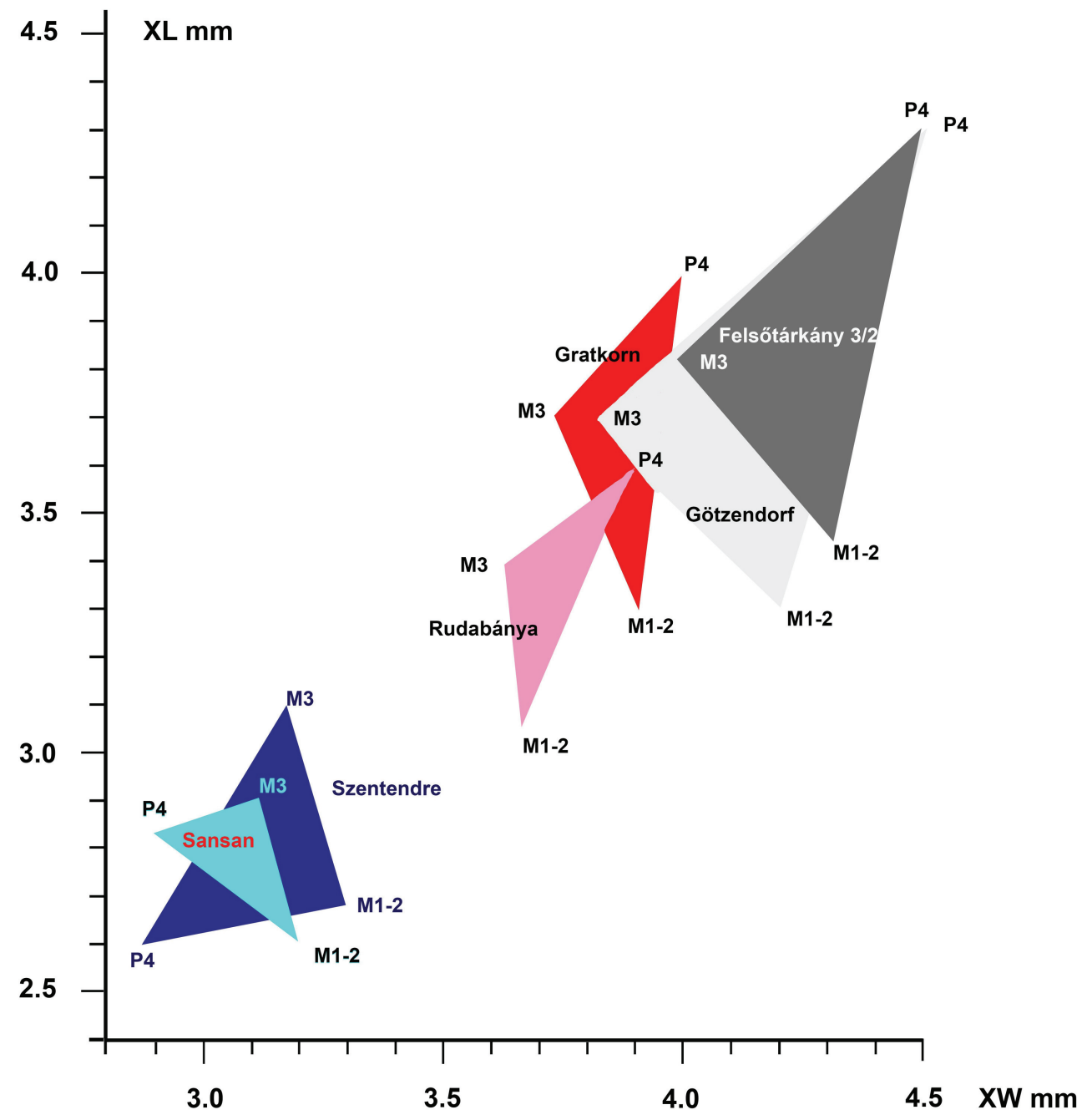

Fig. 26. Scatter diagram of the mean L/W values of selected Albanensia upper premolars and molars 
sis has recently been found in the MN6 fauna of Szentendre. Some typical morphological characters (e.g. enamel crenulation) of the genus are not well developed in this species. In the Szentendre assemblage the dominant hamster is $C$. aureus. The co-occurrence of $A$. sansaniensis and $C$. aureus is found in the MN6 faunas of France and Switzerland (FORTELIUS 2011). The Cricetodontini of the faunas containing $A$. sansaniensis are as follows: Çandir 2, Turkey: Cricetodon candirensis, Castelnau-d'Arbieu, France: Cricetodon meini, Cricetodon aureus, Crastes, France: Cricetodon aureus, Liet, France: Cricetodon sansaniensis, Rümikon Switzerland: Cricetodon aureus, Sansan, France: Cricetodon sansaniensis.

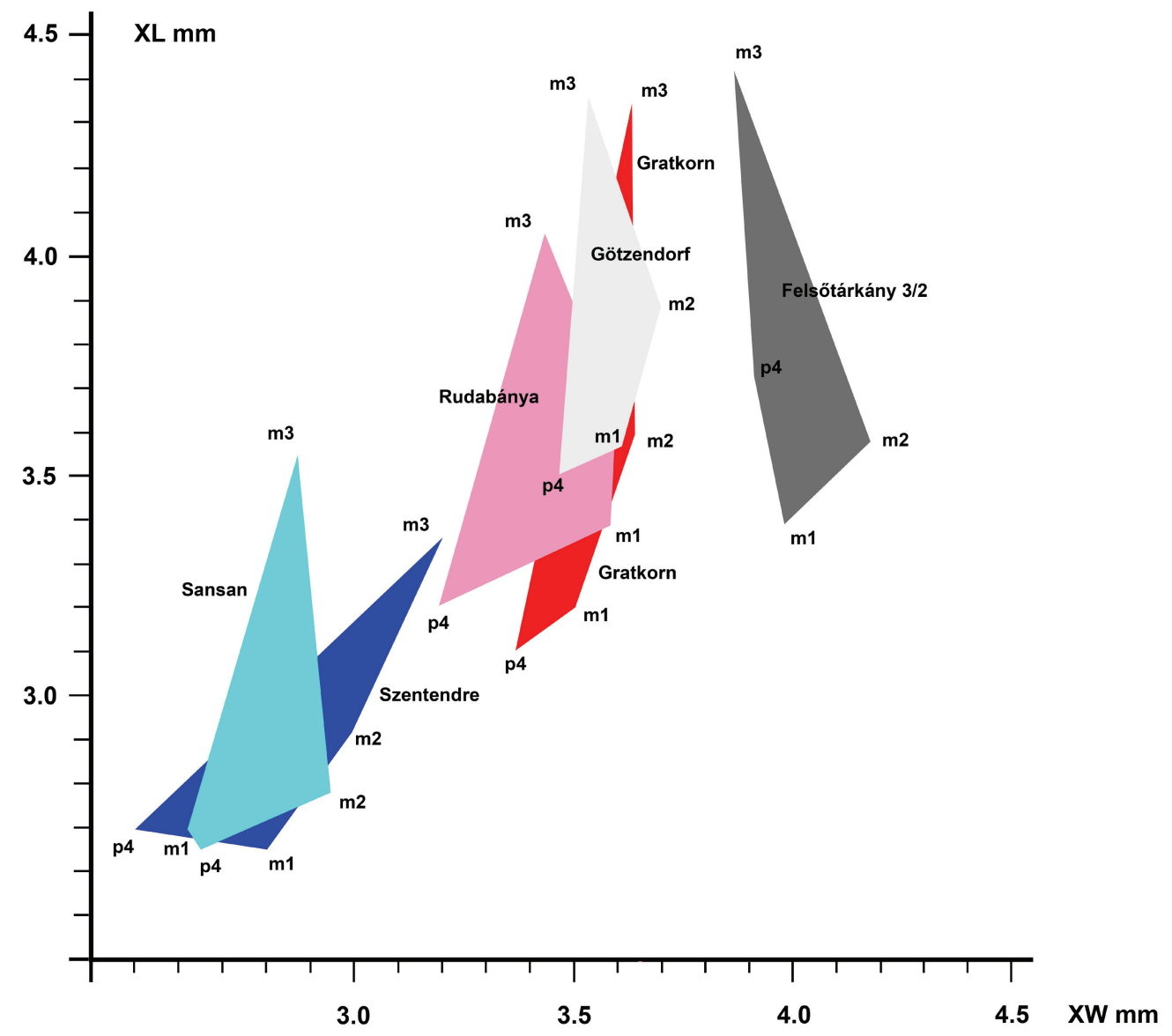

Fig. 27. Scatter diagram of the mean L/W values of selected Albanensia lower premolars and molars 
The two teeth from Mikófalva can be classified as $A$. albanensis. This species refers to the MN7+8 Zone (DAXNER-HöCK 2010). These finds have a biochronological importance for the stratigraphic classification of the Neogene freshwater sands and pebbles which are mapped in the north-western foothill region of the Bükk Mountains.

Two $A$. grimmi assemblages are known in Northern Hungary: Felsőtárkány $3 / 2$ and Rudabánya. The Felsőtárkány material has more typical $A$. grimmi characters than the population from Rudabánya. The dimensions of the teeth from Felsőtárkány $3 / 2$ are close to the $A$. grimmi finds from Marktl, Götzendorf, Hammerschmiede, and Richardhof Golfplatz (DAXner-Höck 2004; MAYR \& FAHLBUSCH 1975). The measurements of the finds from Rudabánya are definitely smaller and there are some morphological differences related to the teeth from Felsőtárkány $3 / 2$ (Table 8). These special markers of the Rudabánya population are not understood, only speculative interpretations are possible.

The occurrences of the European and Anatolian flying squirrels are listed by Casanovas-Vilar et al. (2015) and Fortelius (2011). These summaries demonstrate that latest Albanensia occurrences are found in the faunas of the MN10 Zone from France to Austria. A newest MN10 occurrence is in Pezinok, Slovakia (JoNIAK 2016). For this reason, Albanensia can be regarded as a characteristic victim of the so-called „Vallesian crisis” (Agustí \& MoYÁ-Solá 1990), which was initially recognized in the Vallès-Penedès Basin in Catalonia and implied the disappearance of many forest-adapted species. However, other genera of flying squirrels (Miopetaurista, Neopetes, Pliopetes, Pliopetaurista, Blackia) survived the "Vallesian crisis" and occurred up to the Pliocene MN 15 Zone (DE BRUIJN 1999).

Acknowledgements - The author would like to express his sincere thanks for Dr. Gudrun Daxner-Höck for her personal advices for the valuation and classification of the material of Felsőtárkány, for Dr. Klára Palotás, head of the Collection of the Mining and Geological Survey of Hungary for her kind permission for the study of the Albanensia material of Rudabánya. The field activity was supported by the OTKA (Hungarian Scientific Research Fundation) projects T 046719, T 115472 and NKFI (National Research, Development and Innovation) project K 131894.

\section{REFERENCES}

Abdul-Aziz H., Böhme M., Rocholl A., Zwing A., Prieto J., Wijbrans J., Heissig K. \& BACHTADSE V. 2008: Integrated stratigraphy and ${ }^{40} \mathrm{Sr} /{ }^{39} \mathrm{Ar}$ chronology of the Early to Middle Miocene Upper Freshwater Molasse in eastern Bavaria (Germany). - International Journal of Earth Sciences (Geologische Rundschau) 97: 115-134. https://doi.org/10.1007/s00531-006-0166-7 
Adrover R. 1987: La fauna de roedores en el Aragoniense medio del Barranco del Candel, Buñol (Provincia de Valencia, España). - Paleontologia y Evolució 21: 43-61.

Agustí J. \& MoyÁ-SolÁ S. 1990: Mammal extinctions in the Vallesian (Upper Miocene). Lecture Notes in Earth Sciences 30: 425-432.

Andreánszky G. 1956: Neue und interessante tertiäre Pflanzenarten aus Ungarn II. - Annales historico-naturales Musei nationalis hungarici 7: 221-229.

BoDA J. 1959: Das Sarmat in Ungarn und seine Invertebraten-fauna. - Jabrbuch der Ungarischen Geologischen Anstalt 47(3): 567-862.

BodA J. 1974: A magyarországi szarmata emelet rétegtana. (Stratigraphie des Sarmats in Ungarn.) - Földtani Közlöny 104(3): 249-260. (in Hungarian with German abstract)

Casanovas-Vilar I., Almécija S. \& Alba D. 2015: Late Miocene flying squirrels from Can Llobateres 1 (Vallès-Penedès Basin, Catalonia): systematics and paleobiogeography. - Palaeobiodiversity and Palaeoenvironments 95: 353-372. https://doi.org/10.1007/s12549-015-0192-1

Cuenca-Bescos G. 1988: Revision de los Sciuridae del Aragoniense y del Rambliense en la fossa de Calatayud-Montalban. - Scripta Geologica 87: 1-115.

DAXNER-Höck G. 2004: Flying Squirrels (Pteromyinae, Mammalia) from the Upper Miocene of Austria. - Annalen des Naturhistorischen Museums in Wien, Serie A 106: 387-423.

Daxner-Höck G. 2010: Sciuridae, Gliridae and Eomyidae (Rodentia, Mammalia) from the Middle Miocene of St. Stefan in the Gratkorn Basin (Styria, Austria). - Annalen des Naturhistorischen Museums in Wien, Serie A 112: 507-536.

Daxner-Höck G. \& Höcк E. 2015: Catalogus Fossilium Austriae. Band 4: Rodentia neogenica. Verlag der Österreichischen Akademie der Wissenschaften, Wien, 158 pp.

De Bruijn H. 1999: Superfamily Sciuroidea. - In: Rössner G. \& Heissig K. (eds): The Miocene Land Mammals of Europe, Verlag Dr. Friedrich Pfeil, München, pp. 271-280.

De Bruijn H., Van den Hoek Ostende L., Kristkoiz-Boon E., Rummel M., Theocharopoulos C. \& ÜNAY E. 2003: Rodents, lagomorphs and insectivores, from the middle Miocene hominoid locality of Çandir (Turkey). - Courier Forschungs-Institut Senckenberg 240: 51-87.

DÉR I. 1957: Egercsehi környéki riolittufák vizsgálata. (Studies on rhyolite tuffs around Egercsehi, North Eastern Hungary.) - Földtani Közlöny 87: 343-345. (in Hungarian with English abstract)

Feru M., Radulescu C. \& Samson P. 1979: La faune de Micromammifères de Tauț (dép. D’ Arad). - Travaux de L' Institut de Spéologie "Emile Racoviţa” 18: 185-190.

ForTelius M. 2011: Neogene of the Old World Database of Fossil Mammals (NOW). - University of Helsinki, http://www.helsinki.fi/science/now

Ginsburg M. \& Mein P. 2012: Les Sciuridae (Rodentia) de Sansan. - In: Peigné S. \& Sen S. (eds): Mammifères de Sansan. - Mémoires du Muséum national d'Histoire naturelle 203: 81-94.

HÁmor G. 1985: A nógrád-cserháti kutatási terület földtani viszonyai. (The geology of the NógrádCserhát area.) - Geologica Hungarica series Geologica 22: 1-307.

Heissig K. 2006: Biostratigraphy of the "main bentonite horizon" of the Upper Freshwater Molasse Bavaria. - Palaeontographica Abt. A 277: 93-102.

HíR J. 2001: New Middle Miocene rodent faunas from Northern Hungary. - Lynx (Praha) n. s. 32: 107-122.

Hír J. 2003: The Middle Miocene (Late Astaracian, MN7/8) Rodent Fauna of Felsőtárkány 3/2 (Hungary). - Acta Palaeontologica Romaniae V.4: 125-136.

Hír J. 2006: Late Astaracian (Late Sarmatian) Lagomorphs and Rodents from Felsőtárkány Felnémet (Northern Hungary). - Beiträge zur Paläontologie 30: 155-173. 
Hír J. 2010: A Mátraszőlős 3. lelőhely késő bádeni (MN7/8) korú rágcsálófaunája. [The fossil rodents of the late Badenian (MN7/8) paleovertebrate locality Mátraszőlős 3.] - A Nógrád Megyei Múzeumok Évkönyve 34: 213-234. (in Hungarian with English abstract)

Hír J. 2015: Előzetes beszámoló a Kozárdi Formáció típusszelvényéből gyűjtött gerinces maradványokról. [A preliminary report on the vertebrate finds collected from the type section of the Kozárd Formation.] - A Dornyay Béla Múzeum Évkönyve 38: 328-347. (in Hungarian with English abstract)

Hí R J. 2016: Középső miocén kisemlősfaunák Nógrádból. [Middle Miocene small mammal faunas from Nógrád County.] - 19. Magyar Öslénytani Vándorgyülés, Program, Elöadáskivonatok, Kirándulásvezetö, Kozárd, 26-28. May, 2016, pp. 18-19. (in Hungarian)

Hír J., Codrea V. \& Prieto J. 2019: Two new early Sarmatian (s. str.) latest middle Miocene rodent faunas from the Carpathian Basin. - Palaeobiodiversity and Palaeoenvironments, https://doi.org/10.1007/s12549-019-00399-y

Hí R. \& KóKAY J. 2004: Middle Miocene molluscs and rodents from Mátraszőlős (Mátra Mountains, Hungary). - Fragmenta Palaeontologica Hungarica 22: 83-97.

Hír J. \& KóKAY J. 2011: Late Badenian (MN7/8) molluscs and rodents from Mátraszőlős 3 (Northern Hungary). - Fragmenta Palaeontologica Hungarica 29: 69-78.

Hír J., Prieto J. \& Stiuca E. 2011: A new interpretation of the Miocene rodent faunas from Comanesti 1 and Taut (W-Romania). - Geobios 44: 215-223.

https://doi.org/10.1016/j.geobios.2011.01.003

Hír J. \& VenCzel M. 2018: A preliminary report on the first results of the re-excavation of the middle Miocene palaeovertebrate locality Szentendre, Cseresznyés-árok (Hungary, Pest County). - Nymphaea, Folia Naturae Bihariae 45: 35-80.

Hír J., Venczel M., Codrea V., Angelone Ch., VAn den Hoek Ostende L., Kirscher U. \& PRIETO J. 2016: Badenian and Sarmatian s. str. from Carpathian area: Overview and ongoing research on Hungarian and Romanian small vertebrate evolution. - Comptes Rendus Palevol 15: 863-875. https://doi.org/10.1016/j.crpv.2016.08.001

Hír J., Venczel M., Codrea V., Rössner G., Angelone Ch., Van den Hoek Ostende L., Rosina V., Kirscher U. \& Prieto J. 2017: Badenian and Sarmatian s.str. from the Carpathian area: Taxonomic notes concerning the Hungarian and Romanian small vertebrates and report on the ruminants from the Felsőtárkány Basin. - Comptes Rendus Palevol 16: 312-332. https://doi.org/10.1016/j.crpv.2016.11.006

Hordijk K., Bosma A., De Bruijn H., Van Dam J., Geraedts C., van den Hoek Ostende L., REUMER J. \& WESSELS W. 2015: Biostratigraphical and palaeoecological implications of the small mammal assemblage from the late early Miocene of Montalvos 2, Teruel Basin, Spain. - Palaeobiodiversity and Palaeoenvironments 95(3): 321-346. https://doi.org/10.1007/s12549-015-0203-2

Howell F. 2004: Foreword. - In: Bernor R., Kordos L. \& Rook L. (eds): Multidisciplinary research at Rudabánya. - Palaeontographia Italica 90: 5-7.

Joniak P. 2016: Upper Miocene rodents from Pezinok in the Danube Basin, Slovakia. - Acta Geologica Slovaca 8(1): 1-14.

KÄLIN D. \& KEMPF O. 2009: High-resolution stratigraphy from the continental record of the Middle Miocene Northern Alpine Foreland Basin of Switzerland. - Neues Jabrbuch für Geologie und Paläontologie 254(1-2): 177-235. https://doi.org/10.1127/0077-7749/2009/0010

Kordos L. 1982: Felső-miocén gerinces fauna Szentendréről. (An upper Miocene vertebrate fauna from Szentendre.) - A Magyar Állami Földtani Intézet Jelentése az 1980. évről: 381-384.

Kordos L. 1986: A hasznosi és a szentendrei felső-miocén hörcsögök (Cricetidae, Mammalia) rendszertani és rétegtani vizsgálata. (Upper Miocene hamsters (Cricetidae, Mammalia) of 
Hasznos and Szentendre: a taxonomic and stratigraphic study.) - A Magyar Állami Földtani Intézet Jelentése az 1984. évröl: 523-553.

Kretzoi M. \& Fejfar O. 2004: Sciurids and Cricetids (Mammalia, Rodentia) from Rudabánya. - Palaeontographia Italica 90: 113-148.

Kretzoi M., Krolopp E., Lőrincz H. \& PÁlfalvy I. 1976: A rudabányai alsópannóniai prehominidás lelőhely flórája, faunája és rétegtani helyzete. (Flora, Fauna und stratigraphische Lage der unterpannonischen Prähominiden-Fundstelle von Rudabánya (NO-Ungarn).) - $A$ Magyar Állami Földtani Intézet Jelentése az 1974. Évröl: 365-394.

MAYR H. \& FAHLBUSCH V. 1975: Eine unterpliozäne Kleinsäugerfauna aus der Oberen SüßwasserMolasse Bayerns. - Mitteilungen der Bayerischen Staatssammlung für Paläontologie und historische Geologie 15: 91-111.

Pelikén P. (ed.) 2005: A Bükk hegység földtana. (Geology of the Bükk Mountains.) - Magyar Állami Földtani Intézet, Budapest, 249 pp.

Rădulescu C. \& SAmson P. 1988: Les Cricétides (Rodentia, Mammalia) du Miocéne (Astaracien Superieur) du Roumanie. - Travaux de L'Institut de Spéologie “Emile Racovitza" 37: 67-78.

Tóтн E. \& Csoma V. 2015: Report on the study of the samples from Kozárd. - Unpublished manuscript, Eötvös Loránd University, Department of Palaeontology, Budapest, 4 pp. 